\title{
QSAR and Anti-Depressant Studies of Some Novel Phenothiazine Derivatives
}

\author{
Nachiket S. Dighe ${ }^{1 *}$, Nikhil N Kute ${ }^{1}$ and Deepak S. Musmade ${ }^{2}$ \\ ${ }^{1}$ Department of Pharmaceutical Chemistry, Pravara Rural College of Pharmacy, \\ Loni, MS, India-413736 \\ ${ }^{2}$ Department of Pharmaceutical Chemistry, Sanjivani College of Pharmaceutical \\ Education and Research, Kopergaon, MS, India-423601 \\ *Corresponding author
}

\section{A B S T R A C T}

\begin{tabular}{|l|}
\hline Ke y w or d s \\
Antidepressant, \\
Phenothiazine, \\
QSAR, Sprague- \\
Dawley Rats. \\
\hline Article Info \\
\hline Accepted: \\
20 January 2017 \\
Available Online: \\
10 February 2017 \\
\hline \hline
\end{tabular}

Antidepressants are the drugs used to treat depression thereby elevates mood and modifies the behavior. The main aims in the development of new antidepressants were greater efficacy, absence of side effects, lack of toxicity in over dose and earlier onset of action. In this study, a series of novel substituted phenothiazine was synthesized and evaluated for antidepressant activity by using or forced swim test (FST). Our synthetic route started from substituted aniline which was reacted with cyclohexanone. The later compound with sulfur powder and iodine led to the formation of the title compounds. Total 12 phenothiazine derivatives, $A_{1}$ to $A_{12}$ were tested for antidepressant activity by using or forced swim test (FST). All the synthesized compounds were subjected to antidepressant activity study on Sprague-Dawley rats by despair swim test. Imipramine was used as standard control. The results showed that all the compounds showed antidepressant activity. Among them two compounds, $\mathrm{A}_{3}$ and $\mathrm{A}_{6}$ showed significant antidepressant activity comparing with standard control imipramine.

\section{Introduction}

Depression is a serious medical issue characterized by a variety of debilitating symptoms, such as persistent sadness and anxiety, chronic fatigue, feelings of worthlessness, disturbances in cognitive functioning and thoughts and attempts of suicide (Ray et al., 2014). Depression has been determined to be the leading cause of disability and the 4th leading contributor to the global burden of disease and is characterized by relapse, recurrence and chronicity (Joanna et al., 2013). Antidepressants are the drugs used to treat depression thereby elevates mood and modifies the behavior. Half a century ago, antidepressants were discovered by serendipity (Benoit Petit et al., 2005). Current treatments for depression either fail to produce recovery or induce unwanted side effects. So there is still a large unmet clinical need (Vincent et al., 2010; Baghai et al., 2006; Slattery et al., 2004). The main aims in the development of new antidepressants were greater efficacy, absence of side effects, lack of toxicity in over dose and earlier onset of action (Eleni, 1997). Elaborate research work has been carried out in the past and continuing in the present to synthesize new 
compounds to meet this depression. The forced swim test (behavioral despair test) and tail suspension test in the rat are widely used for the initial screening of antidepressants. These tests have good predictive validity and allow rapid and economical detection of substances with potential antidepressant like activity. The tests are base on the same principle: measurement of the duration of immobility when rodents are exposed to an inescapable situation. The majority of clinically used antidepressants decrease the duration of immobility.

\section{Materials and Methods}

\section{General}

All commercial solvents, chemicals and reagents were purchased from either Merck or Sigma-Aldrich with the highest purity and used without further purification. Proton nuclear magnetic resonance $\left({ }^{1} \mathrm{H}\right.$ NMR) spectra were recorded on a Bruker Advance II $400 \mathrm{MHz}$ spectrometers and pick positions are illustrated in parts per million $(\delta)$ in DMSO solution and tetramethylsilane $(0.05 \%$ $\mathrm{v} / \mathrm{v})$ as internal standard and coupling constant values $(\mathrm{J})$ are given in Hertz. Analytical thin layer chromatography (TLC) was performed with Merck silica gel plates and visualized with UV irradiation (254 nm) or iodine. Melting points were obtained by open glass capillary using Kjeldahl flask containing liquid paraffin and are uncorrected. The IR spectra were taken by a Jasco FT-IR spectrometer with $\mathrm{KBr}$ as diluent. The elemental analysis for $\mathrm{C}, \mathrm{H}$ and $\mathrm{N}$ was performed by a Costech model 4010 and the percentage values agreed with the proposed structures within $\pm 0.4 \%$ of the theoretical values.

\section{Pharmacology}

Rat-Sprague Dawley (220-255 gm), 8-12 weeks old, were obtained from National
Institute of Bioscience, Pune. They were housed in autoclaved polypropylene cages in groups of 2-3 rats per cage and kept in a room maintained at 19 to $25{ }^{\circ} \mathrm{C}$ and humidity 45 to $65 \%$ with a $12-\mathrm{h}$ light/dark cycle. They were allowed to acclimatize for four days before the experiments and were given free access to Standard sterilized extruded rodent diet was provided ad libitum, Reverse Osmosis water treated with UV light was provided in autoclaved polypropylene bottles and Autoclaved corn cob was used as bedding material.

All procedures of the present study was in accordance with the standard operating procedures of the Prado Pvt. Ltd. guidelines provided by the Committee for the Purpose of Control and Supervision of Experiments on Animals (CPCSEA) as published in The Gazette of India, December 15, 1998. Prior approval of the Institutional Animal Ethics Committee (IAEC) was obtained before initiation of the study (IAEC-13-004).

\section{Antidepressant Activity (Forced Swim Test in Rat)}

Behavioral despair or forced swim test (FST) was proposed as a model to test antidepressant activity by Porsolt et al., (1977) ${ }^{9-10}$. It was suggested that mice or rats when forced to swim in restricted space from where they cannot escape are induced to a characteristic behavior of immobility. This behavior reflects a state of despair which can be reduced by several agents which are therapeutically effective in human depression. The behavioral despair test is employed to assess the antidepressant activity of synthesized derivatives. Sprague-Dawley rats of 200-270 gm in a group of two each were used and on the first day of the experiment (pretest session), rats were individually placed in a cylindrical recipient (Plexiglass cylinder) of dimensions (diameter, $10 \mathrm{~cm}$; height, 25 
$\mathrm{cm})$ containing $10 \mathrm{~cm}$ of water $25^{\circ} \mathrm{C}$. The animals were left to swim for $6 \mathrm{~min}$ before being removed, dried and returned to their cages. The procedure was repeated $24 \mathrm{~h}$ later, in 5 min swim session (test session). The synthesized compounds (30 mg kg-1), and imipramine, as a reference antidepressant drug (30 mg kg-1) were suspended in a $0.5 \%$ aqueous solution of $\mathrm{Na} \mathrm{CMC}$ (Corboxy Methyl Cellulose). The drugs were given by gavage in a standard volume of $10 \mathrm{ml} / \mathrm{kg}$ body weight, $1 \mathrm{~h}$ prior to the test. Control animals received $0.5 \%$ aqueous solution of $\mathrm{Na} \mathrm{CMC}$ (Corboxy Methyl Cellulose). This test was performed after $1 \mathrm{hr}, 5 \mathrm{hrs}$ and $24 \mathrm{hrs}$ of dose administration. For individual animal video recording was made.Then, the rats were dropped individually into the Plexiglass cylinder and left in the water for $6 \mathrm{~min}$. After the first $2 \mathrm{~min}$ of the initial vigorous struggling, the animals were immobile. An immobility time is the time spent by mice floating in water without struggling, making only those moment necessary to keep the head above the water. The total duration of immobility was recorded during the last $5 \mathrm{~min}$ of the 6 min test session.

\section{QSAR methodology}

All molecules were drawn in Chem draw ultra 8.0 module in Chemoffice 2004 software and imported into TSAR software. Charges were derived using Charge 2-Derive charges option and optimized by using Cosmic-optimize $3 \mathrm{D}$ option in the structure menu of the project table. Substituents were defined and descriptors were calculated for whole molecule as well as for the Substituents. Several equations were generated correlating both Log (\% Immobilty) with physicochemical parameters (descriptors) by multiple linear regression analysis (MLR) method. Data was standardized by range and leave one out method was used for cross validation. Models were excluded if correlation was exceeding 0.9 for more rigorous analysis. Correlation matrix was generated to find any Intercorrelation between the descriptors. Intercorrelation between the descriptors in the final equation is less than 0.2 (Palomer et al., 2000).

General procedure for the preparation of 2, 3 or 4 substituted N-cyclohexylideneaniline derivatives (I)

Equimolar amount of appropriate aniline was added to a solution of cyclohexanone in $5 \mathrm{~mL}$ of ethanol and the reaction mixture was heated under refluxed at about $80^{\circ} \mathrm{C}$ temperature, for $2 \mathrm{~h}$. TLC indicated the end of reaction. The mixture was cooled by addition of a water/ice mixture. The solid was filtered in excellent yield (Scheme 1).

General procedure for the preparation of 2, 3 or 4 substituted 10H-phenothiazine derivatives (II)

Equimolar amount of 2, 3 or 4 substituted Ncyclohexylideneaniline was added to a solution of sulfur powder and iodine in $5 \mathrm{~mL}$ of ethanol. Reaction mixture was heated under reflux with stirring for about $2 \mathrm{~h}$ and poured into ice/water mixture. The precipitate was filtered and washed with cold water (Scheme 1).

Scheme 1 Synthetic rout to 2,3 or 4 substituted $\mathrm{N}$-cyclohexylideneaniline and 2 , 3 or 4 substituted 10H-phenothiazine

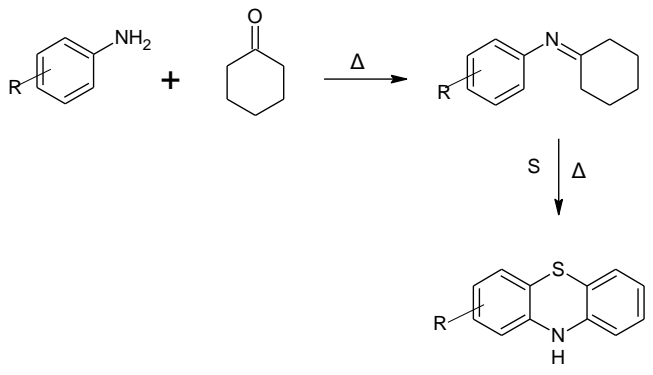




\section{Spectral Data:}

$\mathrm{A}_{1}$ : IR (KBr) $\mathrm{cm}^{-1}: 3213.45$ (-NH str.), 3010.23 (Ar-CH str.), $1525.32 \quad(-\mathrm{C}=\mathrm{N}$ str), 917.76 (-C-S-C- str), 1245.36 (-C-N str.) ${ }^{1} \mathrm{H}$ NMR: $9.61(1 \mathrm{H}-\mathrm{NH}$ sec. amine $), 6.8-7.2(8 \mathrm{H}$ phenyl). m/e(100\%): 199.14

$\mathrm{A}_{2}$ : IR (KBr) $\mathrm{cm}^{-1}$ : 3010.23 (Ar-CH str.), 3213.45 (-NH str.), $1525.32 \quad(-\mathrm{C}=\mathrm{N} \quad$ str $)$, 917.76 (-C-S-C- str), 1245.36 (-C-N str), 1255.36 (-N-O str). ${ }^{1} \mathrm{H}$ NMR: $49.61(1 \mathrm{H}-\mathrm{NH}$ sec. amine), 6.8-7.2 (7H phenyl). $\mathrm{m} / \mathrm{e}(100 \%)$ : 244.13

$\mathrm{A}_{3}$ : IR $\quad(\mathrm{KBr}) \quad \mathrm{cm}^{-1}: 3213.45 \quad(-\mathrm{NH} \quad$ str.), 3010.23 (Ar-CH str.), $1525.32 \quad(-\mathrm{C}=\mathrm{N}$ str), 917.76 (-C-S-C- str), 1245.36 (-C-N str), 1255.36 (-N-O str). ${ }^{1} \mathrm{H}$ NMR: $9.61(1 \mathrm{H}-\mathrm{NH}$ sec. amine), 6.8-7.2 (7H phenyl). $\mathrm{m} / \mathrm{e}(100 \%)$ : 244.15

$\mathrm{A}_{4}$ : IR (KBr) $\mathrm{cm}^{-1}: 3213.45 \quad(-\mathrm{NH} \quad$ str.), 3010.23 (Ar-CH str.), $1525.32 \quad(-\mathrm{C}=\mathrm{N}$ str), 940.21 (C-Cl str.), 1245.36 (-C-N str), 940.23 (-C-Cl str.). ${ }^{1} \mathrm{H}$ NMR: $9.61(1 \mathrm{H}-\mathrm{NH}$ sec. amine), $6.8-7.2$ (7H phenyl). $\mathrm{m} / \mathrm{e}(100 \%)$ : 233.14

$\mathrm{A}_{5}$ : IR (KBr) $\mathrm{cm}^{-1}: 3010.23$ (Ar-CH str.), 1245.36 (-C-N str), 930.21 (-C-Cl str.), 917.76 (-C-S-C- str). ${ }^{1} \mathrm{H}$ NMR: $9.61(1 \mathrm{H}-\mathrm{NH}$ sec. amine), 6.8-7.2 (7H phenyl). $\mathrm{m} / \mathrm{e}(100 \%)$ : 233.12

$\mathrm{A}_{6}$ : IR (KBr) $\mathrm{cm}^{-1}: 3213.45$ (-NH str.), 3010.23 (Ar-CH str.), 1245.36 (-C-N str), $1660.23 \quad$ (-C=O str.), $3500.12 \quad$ (-OH str.), 917.76 (-C-S-C- str). ${ }^{1} \mathrm{H}$ NMR: $9.61(1 \mathrm{H}-\mathrm{NH}$ sec. amine), 12.02 (-1H OH of acid), 6.8-7.2 (7H phenyl). $\mathrm{m} / \mathrm{e}(100 \%): 243.13$

$\mathrm{A}_{7}$ : IR (KBr) $\mathrm{cm}^{-1}: 3213.45$ (-NH str.), 3010.23 (Ar-CH str.), 1245.36 (-C-N str), 940.21 (C-Cl str.), 917.76 (-C-S-C- str). ${ }^{1} \mathrm{H}$ NMR: $9.61(1 \mathrm{H}-\mathrm{NH}$ sec. amine), 6.8-7.2 (7H phenyl). m/e(100\%): 233.11
$\mathrm{A}_{8}:$ IR (KBr) $\mathrm{cm}^{-1}: 3010.23$ (Ar-CH str.), 1245.36 (-C-N str), 3650.12 (-OH str.), 917.76 (-C-S-C- str). ${ }^{1} \mathrm{H}$ NMR: $49.61(1 \mathrm{H}-$ $\mathrm{NH}$ sec. amine), $9.41(1 \mathrm{H}-\mathrm{OH}), 6.8-7.2(7 \mathrm{H}$ phenyl). m/e(100\%): 215.09

$\mathrm{A}_{9}$ : IR (KBr) cm ${ }^{-1}: 3213.45$ (-NH str.), 3010.23 (Ar-CH str.), 1245.36 (-C-N str), 3250.12 (-NH str.), 917.76 (-C-S-C- str). ${ }^{1} \mathrm{H}$ NMR: $9.61(1 \mathrm{H}-\mathrm{NH}$ sec. amine), 6.8-7.2 (7H phenyl). m/e(100\%): 294.10

$\mathrm{A}_{10}$ : IR (KBr) $\mathrm{cm}^{-1}: 3010.23$ (Ar-CH str.), 1245.36 (-C-N str), $1260.02 \quad$ (-C-O str), 917.76 (-C-S-C- str). ${ }^{1} \mathrm{H}$ NMR: $9.61(1 \mathrm{H}-\mathrm{NH}$ sec. amine), 6.8-7.2 (7H phenyl). m/e(100\%): 229.14

$\mathrm{A}_{11}$ : IR (KBr) $\mathrm{cm}^{-1}: 3208.12$ (-NH2 str.), 3010.23 (Ar-CH str.), 1245.36 (-C-N str), 917.76 (-C-S-C- str). ${ }^{1} \mathrm{H}$ NMR: $9.61(1 \mathrm{H}-\mathrm{NH}$ sec. amine), 6.8-7.2 (7H phenyl). $\mathrm{m} / \mathrm{e}(100 \%)$ : 324.15

$\mathrm{A}_{12}$ : IR (KBr) cm $\mathrm{cm}^{-1}: 3208.12$ (-NH2 str.), 3010.23 (Ar-CH str.), 1245.36 (-C-N str), 1260.02 (-C-O str), 917.76 (-C-S-C- str). ${ }^{1} \mathrm{H}$ NMR: $9.61(1 \mathrm{H}-\mathrm{NH}$ sec. amine $), 5.16(2 \mathrm{H}$ $\left.\mathrm{CH}_{2}\right)$, 6.8-7.2 (14H phenyl). $\mathrm{m} / \mathrm{e}(100 \%)$ : 305.15

\section{QSAR}

Intercorrelation between the descriptors in the final equations is less than 0.2. Best Equations correlating Log (\% Immobility) with descriptors for series $\left(\mathrm{A}_{1}-\mathrm{A}_{12}\right)$ generated are presented in table 3 .

Where

$\mathrm{Y}=\log (\% \mathrm{Inh})$

$\mathrm{X} 1: \mathrm{C} \log \mathrm{P}$

$\mathrm{X} 2$ = VAMP HOMO (Whole Molecule)

X3 = Dipole Moment Z Component (Whole Molecule)

$\mathrm{X} 4$ = Inertia Moment 2 Length (Whole Molecule) 


\section{Significance of the terms}

$\mathrm{N}=$ No. of Molecules

$\mathrm{s}=$ tandard error --- less is better

$\mathrm{r}=$ correlation coefficient-higher is better $>0.7$

$\mathrm{r}^{2} \mathrm{cv}=$ cross validated $\mathrm{r}^{2}$ - higher is better $>$ 0.5 ,

$\mathrm{F}$ Value $=$ higher is better

Observed and predicted data and graphs are presented in table 4 for series.

Statistical evaluation of the equations is in accepted range. The correlation coefficient is high with less standard error. The residual value and residual variance for each series also is less indicating good predictive power of models. From equation it is observed that two electronic parameters Dipole Moment Z Component (Whole Molecule) and VAMP
HOMO (Whole Molecule) as well as one steric parameter Inertia Moment 2 Length (Whole Molecule) contribute (-0.227, - 1.469 and -0.414 respectively) negatively for the activity so electron withdrawing and less bulky groups may enhance the activity (\%1 Immobility).

\section{Results and Discussion}

The structures, yields and melting points of the compounds have been given in the table 1 . Melting points of the synthesized compounds were sharp indicating that the compounds were pure; the yield value of the compounds also suggested that the chemical methods were reliable for the synthesis of the compound. All spectral data were in accordance with assumed structures.

Table.1 Analytical and physicochemical data of the synthesized compounds $\left(\mathrm{A}_{1}-\mathrm{A}_{12}\right)$

\begin{tabular}{|c|c|c|c|c|c|c|c|c|}
\hline \multirow{2}{*}{$\begin{array}{c}\text { Comp. } \\
\text { Code }\end{array}$} & \multirow[t]{2}{*}{$\mathbf{R}$} & \multirow[t]{2}{*}{ Mol. Formula } & \multirow{2}{*}{$\begin{array}{l}\text { Mol. } \\
\text { Wt. }\end{array}$} & \multirow{2}{*}{$\underset{{ }^{\circ} \mathrm{C}}{\mathrm{M} . P .}$} & \multirow{2}{*}{$\begin{array}{l}\text { Yield } \\
\%\end{array}$} & \multicolumn{3}{|c|}{$\begin{array}{l}\text { Elemental analyses } \\
\text { Calculated (found) }\end{array}$} \\
\hline & & & & & & $\mathrm{C}$ & $\mathbf{H}$ & $\mathbf{N}$ \\
\hline$\overline{\overline{A_{1}}}$ & $\overline{\mathrm{H}}$ & $\mathrm{C}_{12} \mathrm{H}_{9} \mathrm{NS}$ & 199 & $180-185$ & 65 & $\begin{array}{l}72.30 \\
(72.01)\end{array}$ & $\begin{array}{l}4.50 \\
(4.30)\end{array}$ & $\begin{array}{l}7.00 \\
(6.70)\end{array}$ \\
\hline$\overline{\overline{\mathbf{A}_{2}}}$ & $4 \quad 4-\mathrm{NO}_{2}$ & $\mathrm{C}_{21} \mathrm{H}_{8} \mathrm{~N}_{2} \mathrm{O}_{2} \mathrm{~S}$ & 244 & $195-200$ & 262 & $\begin{array}{l}58.5 \\
(58.30) \\
\end{array}$ & $\begin{array}{l}3.26 \\
(3.01) \\
\end{array}$ & $\begin{array}{l}11.45 \\
(11.05) \\
\end{array}$ \\
\hline $\mathbf{A}_{3}$ & $3-\mathrm{NO}_{2}$ & $\mathrm{C}_{12} \mathrm{H}_{8} \mathrm{~N}_{2} \mathrm{O}_{2} \mathrm{~S}$ & 244 & $210-215$ & 65 & $\begin{array}{l}58.5 \\
(58.32) \\
\end{array}$ & $\begin{array}{l}3.26 \\
(3.05)\end{array}$ & $\begin{array}{l}11.45 \\
(11.10)\end{array}$ \\
\hline$\overline{\mathbf{A}_{4}}$ & $3-\mathrm{Cl}$ & $\mathrm{C}_{12} \mathrm{H}_{8} \mathrm{ClNS}$ & 233 & 204-208 & $\overline{252}$ & $\begin{array}{l}61.64 \\
(61.30) \\
\end{array}$ & $\begin{array}{l}3.41 \\
(3.12) \\
\end{array}$ & $\begin{array}{l}5.96 \\
(5.60) \\
\end{array}$ \\
\hline$\overline{\overline{A_{5}}}$ & (4-Cl & $\mathrm{C}_{12} \mathrm{H}_{8} \mathrm{ClNS}$ & 233 & $215-220$ & 60 & $\begin{array}{l}61.64 \\
(61.32)\end{array}$ & $\begin{array}{l}3.41 \\
(3.15)\end{array}$ & $\begin{array}{l}5.96 \\
(5.55)\end{array}$ \\
\hline$\overline{\overline{A_{6}}}$ & 4-COOH & $\mathrm{C}_{13} \mathrm{H}_{9} \mathrm{NO}_{2} \mathrm{~S}$ & 243 & 202-204 & $\overline{252}$ & $\begin{array}{l}64.30 \\
(64.02)\end{array}$ & $\begin{array}{l}3.70 \\
(3.20)\end{array}$ & $\begin{array}{l}5.71 \\
(5.35)\end{array}$ \\
\hline$\overline{\overline{\mathbf{A}_{7}}}$ & $2-\mathrm{Cl}$ & $\mathrm{C}_{12} \mathrm{H}_{8} \mathrm{ClNS}$ & 233 & $210-215$ & $\overline{770}$ & $\begin{array}{l}61.64 \\
(61.32) \\
\end{array}$ & $\begin{array}{l}3.41 \\
(3.20) \\
\end{array}$ & $\begin{array}{l}5.96 \\
(5.65) \\
\end{array}$ \\
\hline$\overline{\mathbf{A}_{8}}$ & $4-\mathrm{OH}$ & $\mathrm{C}_{12} \mathrm{H}_{9} \mathrm{NOS}$ & 215 & $215-220$ & 60 & $\begin{array}{l}66.95 \\
(66.65)\end{array}$ & $\begin{array}{l}4.21 \\
(4.01)\end{array}$ & $\begin{array}{l}6.51 \\
(6.23)\end{array}$ \\
\hline$\overline{\overline{A_{9}}}$ & 4- $\mathrm{NH}_{2}$ & $\overline{\mathrm{C}_{12} \mathrm{H}_{10} \mathrm{~N}_{2} \mathrm{~S}}$ & 294 & $230-235$ & $\overline{660}$ & $\begin{array}{l}67.26 \\
(67.02) \\
\end{array}$ & $\begin{array}{l}4.70 \\
(4.35) \\
\end{array}$ & $\begin{array}{l}13.03 \\
(12.85) \\
\end{array}$ \\
\hline$\overline{\mathbf{A}_{10}}$ & 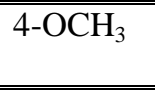 & $\overline{\mathrm{C}_{13} \mathrm{H}_{11} \mathrm{NOS}}$ & 229 & $200-205$ & 65 & $\begin{array}{l}68.58 \\
(68.25) \\
\end{array}$ & $\begin{array}{l}4.84 \\
(4.40) \\
\end{array}$ & $\begin{array}{l}6.11 \\
(5.25) \\
\end{array}$ \\
\hline $\mathbf{A}_{11}$ & $4-\mathrm{I}$ & $\mathrm{C}_{12} \mathrm{H}_{8} \mathrm{INS}$ & 324 & $240-245$ & 65 & $\begin{array}{l}64.32 \\
(64.02) \\
\end{array}$ & $\begin{array}{l}2.48 \\
(2.23) \\
\end{array}$ & $\begin{array}{l}4.31 \\
(4.12) \\
\end{array}$ \\
\hline$\overline{A_{12}}$ & $\begin{array}{l}4-0-\mathrm{CH}_{2-} \\
\mathrm{C}_{6} \mathrm{H}_{5} \\
\end{array}$ & $\overline{\mathrm{C}_{19} \mathrm{H}_{15} \mathrm{NOS}}$ & 305 & $270-275$ & 65 & $\begin{array}{l}74.72 \\
(74.25) \\
\end{array}$ & $\begin{array}{l}4.95 \\
(4.75) \\
\end{array}$ & $\begin{array}{l}4.59 \\
(4.23) \\
\end{array}$ \\
\hline
\end{tabular}


Table.2 Immobility time (sec.) and \% Immobility of the synthesized compounds by despair swim test on rats. $\left(A_{1}-A_{12}\right)$

\begin{tabular}{|c|c|c|c|c|c|c|}
\hline \multirow[t]{2}{*}{ Compound code. } & \multicolumn{3}{|c|}{ Immobility time (sec.) } & \multicolumn{3}{|c|}{ \% Immobility } \\
\hline & $1 \mathrm{Hr}$ & $5 \mathrm{Hr}$ & $24 \mathrm{Hr}$ & $1 \mathrm{Hr}$ & $5 \mathbf{H r}$ & $24 \mathrm{Hr}$ \\
\hline$\overline{A_{1}}$ & 141 & 148.5 & 157.5 & 81.97 & 81.36 & 80.76 \\
\hline$\overline{\mathbf{A}_{2}}$ & 148.5 & 153.5 & 156 & 86.33 & 84.10 & 80.00 \\
\hline$\overline{A_{3}}$ & 143.5 & 149 & 153.5 & 83.43 & 81.64 & 78.71 \\
\hline $\mathbf{A}_{4}$ & 150 & 156 & 158 & 87.20 & 85.47 & 81.02 \\
\hline $\mathbf{A}_{5}$ & 153.5 & 157.5 & 163.5 & 89.24 & 86.30 & 83.84 \\
\hline $\mathbf{A}_{6}$ & 140 & 143 & 145 & 81.39 & 78.35 & 74.35 \\
\hline$\overline{\mathbf{A}_{7}}$ & 145 & 155.5 & 167.5 & 84.30 & 85.20 & 85.89 \\
\hline $\mathbf{A}_{8}$ & 149 & 151 & 157.5 & 86.62 & 82.73 & 80.76 \\
\hline $\mathbf{A 9}_{9}$ & 162.5 & 163 & 165 & 94.47 & 89.31 & 84.61 \\
\hline $\mathbf{A}_{10}$ & 151 & 157.5 & 161 & 87.79 & 86.30 & 82.56 \\
\hline$A_{11}$ & 162.5 & 163 & 165 & 94.47 & 89.31 & 84.61 \\
\hline$A_{12}$ & 151 & 157.5 & 161 & 87.79 & 86.30 & 82.56 \\
\hline Control & 172 & 182.5 & 195 & 100 & 100 & 100 \\
\hline Imipramine std. & 136.5 & 150.5 & 154.5 & 79.41 & 82.49 & 79.26 \\
\hline
\end{tabular}

Table.3 Equations generated between Log (\% Immobility) and descriptors

\begin{tabular}{|l|l|c|c|c|c|c|c|}
\hline Sr. No. & \multicolumn{1}{|c|}{ Equation } & $\mathbf{N}$ & $\mathbf{S}$ & $\mathbf{R}$ & $\mathbf{r}^{2}$ & $\mathbf{r}_{\mathbf{c v}}^{2}$ & $\mathbf{F}$ \\
\hline $\begin{array}{l}\text { series } \\
\left(\mathrm{A}_{1}-\mathrm{A}_{12}\right)\end{array}$ & $\begin{array}{l}\mathrm{Y}=-0.218 * \mathrm{X} 3 \\
-1.576 * \mathrm{X} 2-13.218\end{array}$ & 12 & 0.364 & 0.835 & 0.697 & 0.487 & 13.816 \\
\hline
\end{tabular}


Table.4 Observed and predicted $\log$ (\% Immobility) value data for 12 compounds

\begin{tabular}{|l|c|c|c|c|}
\hline Comp. No. & Observed Value & Predicted Value & Residual Value & $\begin{array}{c}\text { Residual } \\
\text { Variance }\end{array}$ \\
\hline $\mathbf{A}_{\mathbf{1}}$ & 1.842983 & 1.83868347 & -0.0043 & 0.0057 \\
\hline $\mathbf{A}_{\mathbf{2}}$ & 1.821448 & 1.825048019 & 0.0036 & 0.0078 \\
\hline $\mathbf{A}_{\mathbf{3}}$ & 1.828724 & 1.819724327 & -0.009 & 0.0049 \\
\hline $\mathbf{A}_{\mathbf{4}}$ & 1.722634 & 1.718733923 & -0.0039 & 0.0198 \\
\hline $\mathbf{A}_{\mathbf{5}}$ & 1.835881 & 1.840780732 & 0.0049 & 0.0073 \\
\hline $\mathbf{A}_{\mathbf{6}}$ & 1.828724 & 1.836424327 & 0.0077 & 0.0044 \\
\hline $\mathbf{A}_{\mathbf{7}}$ & 1.821448 & 1.807048019 & -0.0144 & 0.0347 \\
\hline $\mathbf{A}_{\mathbf{8}}$ & 1.835881 & 1.829880732 & -0.006 & 0.0184 \\
\hline $\mathbf{A}_{\mathbf{9}}$ & 1.828724 & 1.830024327 & 0.0013 & 0.0092 \\
\hline $\mathbf{A}_{\mathbf{1 0}}$ & 1.821448 & 1.823348019 & 0.0019 & 0.0075 \\
\hline $\mathbf{A}_{\mathbf{1 1}}$ & 1.821448 & 1.817948019 & -0.0035 & 0.0034 \\
\hline $\mathbf{A}_{\mathbf{1 2}}$ & 1.842983 & 1.83868347 & -0.0043 & 0.0057 \\
\hline
\end{tabular}

Figure.1 Antidepressant activity of synthesized compounds by using forced swim method.

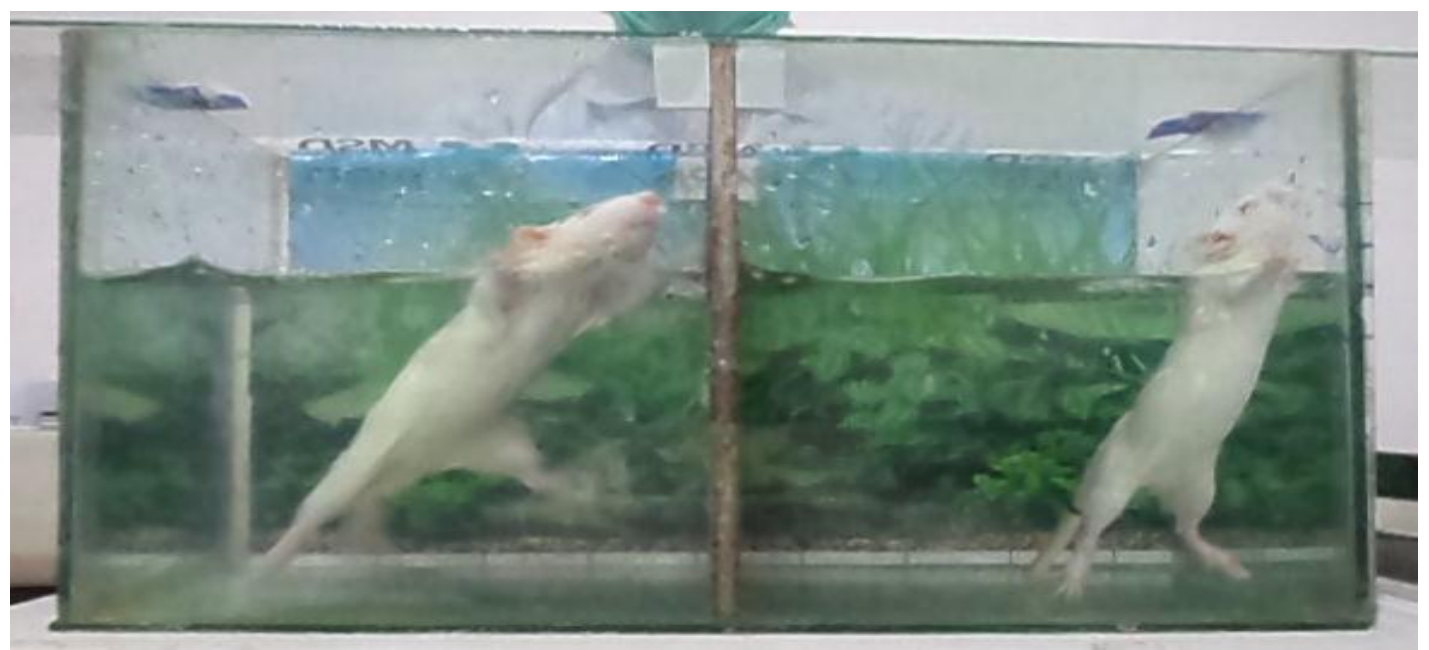

All the synthesized compounds were subjected to antidepressant activity study on Sprague-Dawley rats by despair swim test. Imipramine was used as standard control. The animals show more stable levels of immobility during the last four minutes of the session. The results showed that all the compounds showed antidepressant activity. The results of antidepressant activity for the title compounds were summarized in table 2 and figure 1. 
In conclusion, the present study investigated that the importance of functional group substitutions, in the structural framework of the compounds for their antidepressant activity. All compounds showed significant antidepressant activity at dose $(30 \mathrm{mg} / \mathrm{kg})$. The compounds $\left(A_{3}\right.$, and $\left.A_{6}\right)$ showed better activity. Finally, the encouraging result of the antidepressant activity displayed by these compounds may be of interest for further structural modifications to the lead compound and next level studies in the hope of finding a new potent antidepressant prescription. From these studies, it is clear that further works needed to be done in the future for the development of clinically useful agents.

Author's contribution: NSD: Design of target compounds and supervision of the synthetic and pharmacological parts. PSS: Synthesis of the title compounds and performed the antidepressant activity. NSB: Collaborated in the antidepressant activity and identifying the structures of target compounds. SBD: Collaborated in the antidepressant activity. RBL: Collaborated in the QSAR study. All authors read and approved the final manuscript.

Acknowledgement: Authors wish to express their sincere thanks to Dr. Govind S. Asane, Principal, Pravara rural college of pharmacy, Loni for his constant encouragement and support.

\section{References}

Baghai, T.C., Volz, H.P., Moller, H.J. 2006. Drug treatment of depression in the 2000s: An overview of achievements in the last 10 years and future possibilities. World J. Biol. Psychiatry, 7: 198-222.
Benoit Petit - Demouliere, Franck Chenu, Michel Bourin. 2005. Forced swimming test in mice: A review of antidepressant activity. Psychopharmacol., 177: 245-255.

Eleni Palazidou. 1997. Development of new antidepressants. Adv. Psychiatric treatment, 3: 46-51.

Joanna, L., Iddon, Lee Grant. 2013. Behavioral and cognitive treatment interventions in depression: An analysis of the evidence base. Open J. Depression, 2(2): 11-15.

Palomer, J.J., Pérez, S., Navea, O., Llorens, J., Pascual, L., García, D., Mauleón. 2000. J. Med. Chem., 43: 2280.

Porsolt, R.D., Anton, G., Blavet, N., Jalfre, M. 1978. Behavioural despair in rats: a new model sensitive to antidepressive treatments. Eur. J. Pharmacol., 47: 379-391.

Porsolt, R.D., Bertin, A., Jalfre, M. 1977. Behavioural despair in mice: A primary screening test for antidepressants. Arch. Int. Pharmacodyn., 229: 327-333.

Ray, M., Merrill, Arielle, A., Sloan. 2014. Associations between the uses antidepressants and other medications, Open J. Depression, 3(1): 24-31.2014.31007.

Slattery, D.A., Hudson, A.L., Nutt, D.J. 2004. Invited review: The evolution of antidepressant mechanisms. Fundam. Clin. Pharmacol., 18: 1-21.

Vincent Castagne, Paul Moser, Sylvain Roux, Roger, D., Porsolt. 2010. Rodent models of depression: Forced swim and tail suspension behavioral despair tests in rats and mice. Curr. Protocols in Pharmacol., 49: 5.8.15.8.14.

Vincent Castagne, Paul Moser, Sylvain Roux, Roger, D., Porsolt. 2010. Rodent models of depression: Forced swim and tail suspension behavioral despair tests in rats and mice. Curr. Protocols in Pharmacol., 49: 5.8.15.8.14.

\section{How to cite this article:}

Nachiket S. Dighe, Nikhil N Kute, Deepak S. Musmade. 2017. QSAR and Anti-Depressant Studies of Some Novel Phenothiazine Derivatives. Int.J.Curr.Microbiol.App.Sci. 6(2): 1016-1023. doi: http://dx.doi.org/10.20546/ijcmas.2017.602.114 